\title{
CITRA MEREK SERTA KEPUTUSAN PEMBELIAN PADA CAFE WARUNK UPNORMAL
}

\section{BRAND IMAGE, PURCHASING DECISION AT WARUNK UPNORMAL}

\author{
Fitria Atni Nurjannah ${ }^{1}$, Egi Arvian Firmansyah ${ }^{2}$ \\ 1,2 (Universitas Padjajaran) \\ ${ }^{1}$ fitriaatni14@gmail.com, ${ }^{2}$ agi.firmansyah@unpad.ac.id
}

\begin{abstract}
Abstrak
Penelitian ini bertujuan menggambarkan citra merek dan keputusan pembelian di Warunk Upnormal cabang Dipatiukur Bandung.Untuk memperoleh data dalam penelitian ini, kami menggunakan instrumen kuesioner yang disebarkan ke 100 responden (konsumen) yang berasal dari kota Bandung dan luar kota Bandung. Hasil penelitian menunjukan bahwa citra merek Warunk Upnormal cabang Dipatiukur,dituangkan kedalam beberapa indikator citra merek, hasilnya baik. Hasil penelitian menunjukan bahwa berkenaan dengan skor sub variabel dari keputusan pembelianhasilnya juga baik. Factor-faktor yang paling berpengaruh dalam keputusan pembelian dalam penelitian ini adlaah faktor pribadi dan faktor psikologis.
\end{abstract}

Kata kunci: Citra merek, Keputusan Pembelian, Kota Bandung, Warunk Upnormal

\begin{abstract}
This studyaims at describing the brand image and purchasing decisions in Warunk Upnormal Dipatiukur branch of Bandung. To obtain the data, we used questionnaires instruments distributed to 100 respondents (consumers) who came from the city of Bandung and others. The results showed that the brand image of Warunk Upnormal branch Dipatiukur, proxied by several indicators of brand image, is good. The results also showed that the sub-variable scores of purchasing decisions are also good. The most influential factors in purchasing decisions in this study are personal factors and psychological factors.
\end{abstract}

Keywords: Brand image, Purchasing Decision, Bandung City, Warunk Upnormal,

\section{PENDAHULUAN}

Kota Bandung merupakankota wisata yang banyak dikunjungi oleh para wisawatan pada akhir pekan maupun hari libur nasional. Setiap tahunnya, wisatawan yang mengunjungi kota Bandung selalu mangalami peningkatanan dari tahun ke tahun. Selama periode semester pertama di tahun 2016, yakni Januari sampai Juni 2016, kunjungan wisatawan nusantara dan mancanegara yang mengunjungi Kota Bandung mencapai 6,5 juta pengunjung (Disparbud kota Bandung, 2016). Data statistik tersebut sudah melewati capaian periode semester pertama di tahun 2015 yang hanya mencapai 2 juta pengunjung. Hal tersebut dapat menjadi tolak ukur bahwa kota Bandung mempunyai daya tarik wisata yang diminati oleh para wisatawan.Hal ini juga disebabkan oleh beberapa faktor diantaranya berkembangnya wisata kuliner di kota Bandung yang semakin kreatif dan inovatif sehingga menarik minat para wisatawan.Jumlah populasi kota Bandung pada tahun 2016 adalah 2.490.622 jiwa dan akan terus meningkat setiap tahunnya terbukti laju pertumbuhan penduduk pada tahun 2011-2016 
yang terus mengalami peningkatan. Adanya peluang tersebut membuat para pengusaha kuliner membuka tempat kuliner mulai dari kaki lima hingga cafe atau restoran. Berikut adalah jumlah restoran atau rumah makan di kota Bandung pada tahun 2016.

Tabel 1. Jumlah Restoran/Rumah Makan di Kota Bandung tahun 2016

\begin{tabular}{lc}
\hline \multicolumn{1}{c}{ Kategori } & Jumlah \\
\hline Restoran & 396 \\
Rumah Makan & 372 \\
Cafe & 14 \\
Bar & 13
\end{tabular}

Sumber: Laporan Disbudpar Kota Bandung mengenai “Jumlah Restoran/Rumah Makan di Kota Bandung" tahun (2016)

Berdasarkan Tabel 1, dapat dilihat bahwa jumlah restoran/rumah makan di kota Bandung yang jumlahnya cukup banyak. Hal tersebut membuat persaingan antar pelaku bisnis kuliner dikota Bandung menjadi sangat ketat. Datangnya para pengusaha kuliner dikota Bandung yang semakin meningkat juga membuat persaingan semakin ketat. Untuk menghadapi persaingan di dunia kuliner, para pelaku industri makanan dan minuman semakin bersaing dengan menciptakan keunggulan yang kompetitif agar perusahaan dapat berkembang dan bertahan dimasa yang akan datang.

Dalam memilih suatu produk, konsumen memiliki banyak bahan pertimbangan hingga akhirnya dapat memutuskan untuk memilih suatu produk. Citra merek yang menjadi salah satu faktor yang dapat mempengaruhi perilaku konsumen sehingga menimbulkan minat dan daya tarik konsumen terhadap suatu produk, hingga akhirnya memutuskan untuk melakukan pembelian suatu produk. Jika suatu produk telah mempunyai citra merek yang baik, maka tidak sulit untuk para pelaku bisnis menarik konsumen untuk membeli produk tersebut.

Persaingan yang semakin ketat antar para pelaku usaha kuliner di kota Bandung membuat para pengusaha berlomba-lomba untuk terus meningkatkan keunggulan pada masing-masing produk untuk menarik dan mempengaruhi konsumen dalam melakukan proses keputusan pembelian. Salah satu upaya yang dapat dilakukan para pengusaha kuliner adalah dengan terus meningkatkan kreatifitas dan inovasi pada produk. Inovasi produk sangatlah penting bagi para pengusaha kuliner karena hal tersebut dapat meningkatkan citra merek dari produk tersebut dan dengan citra merek yang baik maka akan tercipta loyalitas 
merek (brand loyalty) dari konsumen dan mempengaruhi keputusan pembelian konsumen terhadap satu produk. Keller (1998:93) mengungkapkan bahwa citra merek yaitu “....a perception about brand as reflected by the brand association held in consumer memory".Dari definisi tersebut, dapat dikatakan bahwa citra merek merupakan persepsi dari masing-masing konsumen tentang merek yang tercemin dari pandangan yang dimiliki oleh setiap konsumen terhadap asosiasi merek dan hal tersebut dapat berbeda-beda tergantung dari pandangan dari setiap individu konsumen.

Dari sekian banyak pilihan kuliner di kota Bandung, salah satu jenis makanan yang paling banyak disukai oleh para konsumen adalah mi instan dan salah satu merek mi instan yang paling populer di Indonesia adalah Indomie. Indomie adalah merek produk mie instan dari Indonesia yang diproduksi oleh PT. Indofood CBP Sukses Makmur Tbk. yang memiliki banyak pilih rasa. Seiring perkembangan jaman, banyak inovasi yang dibuat oleh para pelaku usaha dengan mengolah Indomie menjadi makanan yang lebih variatif. Peluang tersebut dilihat oleh Owner Warunk Upnormal untuk memulai bisnisnya pada bulan Juli tahun 2014.

Warunk Upnormal adalah cafe yangbanyak digemari oleh konsumen kota Bandung maupun para wisatawan luar kota Bandung.Hal ini terbukti dari banyaknya cabang Warunk Upnormal yang telah dibuka dan tersebar di berbagai wilayah.Tempat yang nyaman dan adanya fasilitas pendukung membuatbrand Warunk Upnormal memiliki citra merek yang unik. Warunk Upnormal juga menawarkan produk yang berbeda dari yang lainnya yaitu menu utama Indomie dengan level yang lebih berkelas. Jenis produk yang ditawarkan oleh Warunk Upnormal membuat konsumen tertarik untuk datang dan melakukan pembelian di Warunk Upnormal.

Seiring perkembangan waktu,Warunk Upnormal bukan menjadi satu-satunya cafe yang menyediakan olahan Indomie yang unik. Telah banyak pesaing yang memiliki konsep yang sama dengan Warunk Upnormal yaitu menyediakan menu Indomie olahan yang unik dan disajikan ditempat nyaman serta fasilitas yang memadai. Walaupun Warunk Upnormal telah mempunyai citra yang baik dimata konsumen sebagai pelopor cafe dengan olahan Indomie yang unik, namun Warunk Upnormal tetap harus meningkatkan kreativitas dalam produknya,menciptakan strategi-strategi dan ide-ideyang inovatif, menjaga kualitas produk dan merenovasi lokasi serta meningkatkan fasilitas yang adademi mempertahankan citra mereknya.

Memiliki citra merek yang kuat merupakan suatu keharusan bagi setiap perusahaan. Pengaruh citra merek dinilai merupakan hal yang sangat penting dalam hal memasarkan 
sebuah produk maupun jasa. Keller (1998) menyatakan bahwa citra merek mempunyai faktor-faktor penentu dalam keterkaitannya dengan asosiasi merek. Faktor-faktor tersebutmeliputi keunggulan asosiasi merek (favorability of brand association), kekuatan asosiasi merek (strength of brand association), dan keunikan asosiasi merek (uniqueness of brand association). Para pengusaha harus memperhatikan faktor-faktor apa saja yang berhubungan dengan citra merek. Hal ini dilakukan agar Warung Upnormal juga dapat mengetahui produk apa saja yang kurang diminati konsumen serta produk apa saja yang paling diminati oleh konsumen. Sehingga, Warung Upnormal dapat melakukan inovasi halhal baru sesuai kebutuhan dan keinginan konsumen.

Cabang Warunk Upnormal yang tersebar di beberapa wilayah memiliki target konsumen tersendiri pada daerah dimana Warunk Upnormal tersebut berdiri. Warunk Upnormal juga mempunyai tantangan yang berbeda-beda pada setiap cabangnya walaupun Warunk Upnormal mempunyai citra yang sama baiknya pada setiap cabang. Berdasarkan uraian diatas, penelitian ini bertujuan menggambarkan citra merek (brand image) dan keputusan pembelian konsumen Warunk Upnormal cabang Dipatiukurkota Bandung.

Secara lebih spesifik, penelitian inibertujuan menggambarkan tanggapan responden mengenaikeunggulan asosiasi merek (favorability of brand association), tanggapan responden mengenai kekuatan asosiasi merek (strength of brand association, tanggapan responden mengenai keunikan asosiasi merek (uniqueness of brand association), serta tanggapan responden mengenai keputusan pembelian pada Warung Upnormal cabang Dipatiukurkota Bandung.

\section{Citra Merek}

Citra merek yaitu memori atau ingatan akan sebuah merek, yang berisiinterpretasi konsumen atas atribut, kelebihan, penggunaan, situasi, para pengguna, dan karakteristik pemasar atau karakteristik pembuat dari produk/merek tersebutSetiadi (2003). Citra merek adalah apa yang konsumen pikirkan dan terlintas dibenak konsumen ketika mendengar atau melihat suatu merek. Ferrinadewi (2008) berargumen bahwa citra merek ialah hal subjektif berdasarkan emosi diri sendiri yang dibuat oleh konsumen tersebut. Artinya dari kedua pendapat ahli diatas dapat disimpulkan bahwa pandangan konsumen terhadap citra merek timbul berdasarkan pendapat ataupun opini dari dalam diri konsumen itu sendiri. Pendapat konsumen terhadap citra merek tersebut tentunya didukung oleh beberapa faktor yang mempengaruhi citra merek sehingga konsumen dapat menyimpulkan pandangannya terhadap citra merek tersebut. 
Menciptakan keunikan asosiasi merek dapat dilakukan dengan cara diferensiasi. Diferensiasi dapat berupa ukuran, bentuk, model, atau struktur fisik suatu produk (Kotler \& Keller, 2006). Hal ini dilakukan untuk menciptakan keunikan pada suatu merek dengan menciptakan keunikan pada suatu produk, pelayanan, personalia, maupun pada citra.

\section{Keputusan Pembelian}

Keputusan pembelian adalah proses integrasi yang membaurkan sikap pengetahuan dalam proses evaluasi dua atau lebih perilaku alternatif, kemudian memilih salah satu diantaranya (Setiadi, 2003). Artinya, konsumen mempunyai suatu tindakan untuk memutuskan membeli sautu produk atau tidak. Hal tersebut diputuskan oleh konsumen dengan mengevaluasi beberapa pilihan yang ada dan dilihat melalui beberapa faktor pendukung seperti mempertimbangkan kualitas, produk, pelayanan, maupun harga.

Terdapat beberapa proses pengambilan keputusan konsumen mulai dari pengenalan kebutuhan hingga perilaku pasca pembelian yang dapat dikatan pula sebagai pengalaman yang dirasakan oleh konsumen terhadap suatu produk. Pengalaman baik konsumen terhadap suatu produk sangatlah penting mengingat dalam proses pengambilan keputusan konsumen tidak hanya bertindak dalam pengambilan keputusan namun juga akan menjadi pengalaman konsumen yang nantinya akan berpengaruh pada produk tersebut dikemudian hari. Sebelum konsumen memutuskan untuk memilih suatu produk hingga akhirnya membeli produk tersebut, konsumen akan melalui beberapa tahap terlebih dahulu yaitu (Kotler, 2002) pengenalan masalah, pencarian informasi, evaluasi alternatif, keputusan pembelian, dan perilaku pascapembelian.Menurut Kotler (2002),perilaku pembelian konsumen dipengaruhi oleh empat faktor, diantaranya faktor budaya, faktor sosial, faktor pribadi dan faktor psikologis.

\section{Penelitian Terdahulu}

Penelitian terkati citra merek dan keputusan cukup banyak dilakukan dalam penelitian sebelumnya. Dalam penelitian ini, kami mempelajari penelitian tersebut sebagai dasar dalam pembahasan.Ada pun penelitian tersebut diantaranya disajikan dalam tabel 2 . 
Tabel 2. Penelitian Terdahulu

\begin{tabular}{|c|c|c|c|c|c|}
\hline No. & Judul Penelitian & Penulis & Metode & Variabel & Hasil \\
\hline 1. & $\begin{array}{l}\text { Pengaruh Citra Merek } \\
\text { Terhadap Pengambilan } \\
\text { Keputusan Pembelian } \\
\text { Sepatu Nike pada } \\
\text { Mahasiaswa FIK UNY }\end{array}$ & (Romadhoni, 2015) & $\begin{array}{l}\text { Metode survei } \\
\text { dengan } \\
\text { instrumen } \\
\text { angket }\end{array}$ & $\begin{array}{l}\text { Citra Merek (Keunggulan } \\
\text { Asosiasi Merek, Kekuatan } \\
\text { Asosiasi Merek, Keunikan } \\
\text { Asosiasi Merek)dan } \\
\text { Keputusan Pembelian }\end{array}$ & $\begin{array}{l}\text { Keputusan Pembelian konsumen terhadap pembelian } \\
\text { mobil Toyota Kijang Innova dipengaruhi oleh variasi } \\
\text { dari ketiga variabel independen, yaitu keunggulan } \\
\text { asosiasi merek, kekuatan asosiasi merek, keunikan } \\
\text { asosiasi merek. }\end{array}$ \\
\hline 2. & $\begin{array}{l}\text { Pengaruh Citra Merek } \\
\text { Terhadap Pengambilan } \\
\text { Keputusan Pembelian } \\
\text { (Survei pada Konsumen } \\
\text { KFC kawi malang) }\end{array}$ & (Musay, 2013) & $\begin{array}{l}\text { Metode } \\
\text { penelitian } \\
\text { kuantitatif }\end{array}$ & $\begin{array}{l}\text { Citra Perusahaan (X1), Citra } \\
\text { Pemakai (X2) dan Citra } \\
\text { Produk (X3). -dan Keputusan } \\
\text { Pembelian (Y) }\end{array}$ & $\begin{array}{l}\text { Sebesar 39,2\% keputusan pembelian dapat dijelaskan } \\
\text { oleh ketiga variabel independen yaitu Citra } \\
\text { Perusahaan (X1), Citra Pemakai (X2), dan Citra } \\
\text { Produk (X3). Sedangkan sisanya sebesar 60,8 \% } \\
\text { dipengaruhi oleh variabel-variabel lain yang tidak } \\
\text { diteliti dalam penelitian ini. }\end{array}$ \\
\hline 3. & $\begin{array}{l}\text { Analisis Citra Merek } \\
\text { Terhadap Pengambilan } \\
\text { Keputusan } \\
\text { PembelianKartu Simpati } \\
\text { di Yogja }\end{array}$ & (Listyawati, 2014) & Metode survei & $\begin{array}{l}\text { Citra pembuat (X1), Citra } \\
\text { pengguna (X2), Citra produk } \\
\text { (X3). } \\
\text { dan Keputusan Pembelian }\end{array}$ & $\begin{array}{l}\text { Pengaruh variabel citra pembuat (X1), citra } \\
\text { pengguna (X2) dan citra produk (X3) terhadap } \\
\text { keputusan pembelian sebesar 64,4\% sedangkan } \\
\text { sisanya 35,6\% dipengaruhi oleh variabel lain di luar } \\
\text { penelitian ini. }\end{array}$ \\
\hline 4. & $\begin{array}{l}\text { Analisis Citra Merek } \\
\text { Terhadap Pengambilan } \\
\text { Keputusan Pembelian } \\
\text { (Studi Kasus pada Bakso } \\
\text { Boejangan Cabang } \\
\text { Burangrang Bandug) }\end{array}$ & (Evita Nurul, 2017) & $\begin{array}{l}\text { Metode } \\
\text { kuantitatif dan } \\
\text { jenis penelitian } \\
\text { deskriptif } \\
\text { verifikatif }\end{array}$ & $\begin{array}{l}\text { Variabel independen yaitu } \\
\text { Citra merek dan variabel } \\
\text { dependen keputusan } \\
\text { pembelian. }\end{array}$ & $\begin{array}{l}\text { Pengaruh Citra merek terhadap Keputusan pembelian } \\
\text { adalah sebesar 59,5\% dan sisanya adalah sebesar } \\
\text { 40,5\% dipengaruhi oleh faktor-faktor lainnya yang } \\
\text { tidak diteliti seperti harga dan kualitas produk dan } \\
\text { pelayanan. }\end{array}$ \\
\hline 5. & $\begin{array}{l}\text { Pengaruh Citra Merek } \\
\text { Terhadap Pengambilan } \\
\text { Keputusan Pembelian } \\
\text { SmartPhone Android } \\
\text { Samsung di Kota } \\
\text { Palembang }\end{array}$ & $\begin{array}{l}\text { (Syoalehat, Azizah, } \\
\text { \& Kusumastuti, } \\
\text { 2016) }\end{array}$ & Metode survei & $\begin{array}{l}\text { Keunggulan Merek,Kekuatan } \\
\text { Merek, Keunikan Merek. } \\
\text { Keputusan Pembelian. }\end{array}$ & $\begin{array}{l}\text { Variabel kekuatan merek berpengaruh sebesar 54,2\% } \\
\text { terhadap keputusan konsumen atau variabel Y dan } \\
\text { sisanya sebesar45,8\% diperngaruhi oleh variabel lain } \\
\text { yang tidak ditemukan dalam penelitian ini. }\end{array}$ \\
\hline
\end{tabular}


6. Analisis Pengaruh Brand Image Terhadap

Keputusan Nasabah dalam

Memilih Tabungan pada

PT. Bank Central Asia

Cabang Probolinggo.

7. Pemasaran, Daya Tarik

Ekowisata dan Minat

Berkunjung Wisatawan

8. Analisis Pengaruh Citra

Merek Terhadap

Keputusan Konsumen

pada BPR Sejahtera

Batam

9. Analisis Pengaruh Brand Image Terhadap

Pengambilan Keputusan

Konsumen pada PT. Surya

Madistrindo Batam.

10. Analisis Pengaruh Citra

Merek dan Kualitas

Produk

TerhadapKeputusan

Pembelian Laptop Merek

Acer di Kota Semarang
(Lestari, 2011) Metode

kuantitatif

(Widagdyo, 2017)

Metode survey

dan observasi

serta wawancara mendalam

(Hakim, 2016)

Metode Analisis

Deskriptif dan

Regresi Linear

Berganda

(Asmarazisa, 2014) Metode Analisis

Deskriptif dan

Regresi Linear

Berganda

(Sulistyawati,

Metode Analisis

Deskriptif dan

Regresi Linear

Berganda
Citra Pembuat (X1), Citra

Pemakai (X2), Citra Produk

(X3) dan (Y )Keputusan

Memilih

Faktor Petualangan dan

Budaya, Faktor Daya Tarik

Wisata dan Keindahan Alam

serta Faktor Nilai Pranata

Sosial dan Sejarah

Variabel Indepenen : Citra

Produsen (X1), Citra

Konsumen (X2), Citra

Produk (X3).

Variabel Dependen :

Keputusan Pembelian

Citra Produsen (X1), Citra

Konsumen (X2), Citra

Produk (X3).

DanKeputusan Pembelian

Citra Merek, Kualitas

Produk, dan Keputusan

Pembelian. variabel citra pembuat, citra pemakai, dan citra produk secara simultan berpengaruh positif dan signifikan terhadap keputusan nasabah

Hanya Faktor Petualangan dan Budaya dan Faktor Nilai Pranata Sosial dan Sejarah yang memiliki pengaruh terhadap keputusan berkunjung para wisatawan

Sebesar 51,2\% keputusan konsumen dalam memilih produk tabungan dapat dijelaskan oleh variabel citra produsen, citra konsumen dan citra produk, sedangkankeputusan konsumen dalam memilih produk tabungan dipengaruhi oleh variabel-variabel lainnya

$51,2 \%$ keputusan konsumen dalam memilih produk rokok dapat dijelaskan oleh variabel citra produsen, citra konsumen dan citra produk, sedangkan sisanya yaitu sebesar 48,8\% keputusan konsumen dalam memilih produk rokok dipengaruhi oleh variabel-

variabel lainnya

Variabel Citra Merek dan Kualitas Produk mempunyai pengaruh yang signifikan secara simultan terhadap keputusan pembelian Konsumen.

Sumber: Data diolah (2018) 


\section{METODE}

Penelitian ini merupakan penelitian deskriptif dengan objek yang diteliti citra merek dan keputusan pembelian pada Warunk Upnormal Cabang Dipatiukur. Objek penelitian beralamat di Jl. Dipatiukur No.3, LebakGede, Coblong, Kota Bandung, Jawa Baratdan waktu penyebaran kuesioner selama satu bulan yaitu Februari 2018.Pengumpulan data yang digunakan pada penelitian ini adalah penelitian pustaka (library research) dan penelitian lapangan (field research).Penelitian pustaka dilakukan dengan menelaah berbagai buku literatur dan artikel jurnal yang berkaitan dengan masalah yang dibahas. Penelitian lapangandilakukan dengan caraobservasi yaitu melakukan pengumpulan data langsung ke tempat penelitian. Data dikumpulkan melaluikuesioneryang berisi data serta pernyataanpernyataan responden. Dalam penelitian ini, kuesioner yang digunakan menggunakan pernyataan tertutup.

Penelitian ini menggunakan data kualitatif yaitu data yang diperoleh dalam bentuk informasi, baik secara lisan maupun tulisan. Data tersebut kemudian diolah secara kuantitatif menggunakan perangkat lunak Ms. Excel 2013.Data primer digunakan dalam penelitian ini.Data primer dalam penelitian ini diperoleh dari hasil survey dan pengisian kuesioner untuk mengetahui Keunggulan Asosiasi Merek, Kekuatan Asosiasi Merek, dan Keunikan Asosiasi Merek dan keputusan pembelian konsumen. Ada pun data sekunder dalam penelitian ini adalah informasi tertulis dan dokumentasi pada Warunk Upnormal cabang Dipatiukur.

Sebelum menentukan jenis pertanyaan yang akan tertuang didalam kuisioner, kami terlebih dahulu menentukan indikator dari variabel independen dan variabel dependen serta menentukan nomor item yang ditujukan untuk menentukan nomor urut pada kuisioner. Kedua variabel yaitu citra merek dan keputusan pembelian menggunakan skala ordinal, yaitu skala yang bersifat membedakan dan mengurutkan data hasil pengamatan yang diklasifikasikan kedalam beberapa kategori.

Pada penelitian ini, populasi penelitian mengacu pada konsumen Warunk Upnormal cabang Dipatiukur. Jumlah dari pengambilan sampel pada penelitian ini adalah 10.000 orang.Teknik pengambilan sampel yang digunakan adalah teknik Non-Probability Sampling, yaitu teknik pengambilan sampel dengan tidak memberikan kesempatan yang sama bagi setiap unsur atau anggota populasi untuk dipilih menjadi sampel dan dengan metode Convenience Sampling. Kriteria spesifik dalam sampel tersebut diantaranya adalah 1). Merupakan masyarakat Bandung/Pendatang, dan 2) merupakan konsumen Warunk Upnormal yang pernah mengunjungi Warunk Upnormal cabang Dipatiukur. 
Adapun jumlah sampel tersebut diperoleh dari perhitungan yang dikemukakan oleh metode Slovin. Metode Slovin adalah metode yang tepat dan efektif, dapat menggambarkan kondisi populasi yang sesungguh dan akurat.

Rumus metode Slovin:

$$
n=\frac{N}{1+N e^{2}}
$$

Keterangan rumus :

$$
\begin{aligned}
& \mathrm{n}: \text { Jumlah sampel } \\
& \mathrm{N} \text { : Jumlah populasi } \\
& \text { e : Batas toleransi kesalahan (error tolerance) }
\end{aligned}
$$

Dari 10.000 orang jumlah populasi pada penelitian ini dengan batas toleransi kesalahan 10\%, maka sampel dapat ditentukan sebagai berikut:

$\mathrm{n}=\mathrm{N} /\left(1+\mathrm{N} \mathrm{e}^{2}\right)=10.000 /\left(1+10.000 \times 0,1^{2}\right)=99.09>100$

Dengan demikian jumlah sampel yang digunakan dalam penelitian ini adalah 99 orang dan digenapkan menjadi 100 orang. Ada pun teknik pengolahan data yang dilakukan dengan cara mengumpulkan semua data-data yang diperoleh melalui kuisioner dengan 100 orang responden, kemudian kami mengklasifikasikan data sesuai dengan perumusan masalah yang diteliti, kemudian dianalisis dan disusun secara sistematis.Teknik pengolahan data dilakukan untuk mengetahui tanggapan konsumen. Tahapan tersebut adalah: 1). mengumpulkan dan menyeleksi kuesioner, dan 2). menggunakan distribusi frekuensi untuk mengolah data.

\section{HASIL DAN PEMBAHASAN}

\section{Karakteristik Responden}

Dari segi demografi usia, diperoleh data yaitu usia responden penelitian dibawah 20 tahun sebesar $15 \%$, usia 21 tahun sampai dengan 25 tahun sebesar 78\%, 26 tahun sampai 30 tahun sebesar $7 \%$, dan diatas 31 tahun sebesar $0 \%$. Sehingga, hasil penelitian menunjukkan bahwa sebagian besar konsumen Warunk Upnormal cabang Dipatiukur adalah remaja hingga remaja-dewasa (berusia 21 - 25 tahun). Dari segi demografi jenis kelamin, responden didominasi oleh wanita yaitu sebesar 63\% dan laki-laki 37 \%. Berdasarkan asal kota, konsumen Warunk Upnormal cabang Dipatiukur yang didominasi oleh masyarakat kota Bandung yaitu sebesar 86 \% dan diikuti oleh masyarakat luar Bandung atau pendatang yaitu sebesar 14\%. Adapun berdasarkan penghasilan/uang saku konsumen perbulan, hasil penelitian menunjukkan bahwa penghasilan per bulan mayoritas responden sebesar 
Rp1.600.000,00 - 2.500.000,00 yaitu sebesar 75\%, Rp2.600.000,00 - 3.500.000,00 yaitu sebesar $17 \%$, < Rp1.500.000,00 yaitu sebesar $6 \%$, dan >Rp3.600.000,00 yaitu sebesar $2 \%$.

\section{Tanggapan Responden Mengenai Citra Merek}

\section{Tanggapan Responden Mengenai Keunggulan Asosiasi Merek}

Berikut ini adalah hasil dari pengolahan data tanggapan responden mengenai keunggulan asosiasi merek pada indicator pertanyaan item no.1 dan item no.2.

Tabel 3. Item no. 1

\begin{tabular}{clccccc}
\hline No & \multicolumn{1}{c}{ Pertanyaan } & Jawaban & Bobot & F & \% & Skor \\
\hline 1 & Saya merasa & SS & 5 & 22 & $22 \%$ & 110 \\
& nyaman berada & S & 4 & 67 & $67 \%$ & 268 \\
& pada Warunk & CS & 3 & 9 & $9 \%$ & 27 \\
Upnormal cabang & TS & 2 & 1 & $1 \%$ & 2 \\
Dipatiukur. & STS & 1 & 1 & $1 \%$ & 1 \\
\multicolumn{2}{c}{ TOTAL } & & & 100 & $100 \%$ & 408 \\
\multicolumn{2}{c}{ RATA-RATA } & & & & 4.08 \\
\hline
\end{tabular}

Sumber: Data Diolah (2018)

Berdasarkan variabel citra merek dengan dimensi keunggulan asosiasi merek, didapat tanggapan responden terhadap pertanyaan "Saya merasa nyaman berada pada Warunk Upnormal cabang Dipatiukur”. Hasil yang didapat yaitu 22 responden menjawab "Sangat Setuju”, 67 responden menjawab "Setuju”, 9 responden menjawab "Cukup Setuju”, 1 responden menjawab “Tidak Setuju”, dan 1 responden menjawab “Sangat Tidak Setuju”. Hal tersebut membuktikan bahwa sebagian besar konsumen pada Warunk Upnormal cabang Dipatiukur telah merasa nyaman saat berada pada Warunk Upnormal cabang Dipatiukur, dapat dilihat dari Sebagian besar konsumen menjawab setuju merasa nyaman berada pada Warunk Upnormal cabang Dipatiukur. Hal ini seperti ditunjukan dalam tabel 3.

Berdasarkan variabel citra merek dengan dimensi keunggulan asosiasi merek, didapat tanggapan responden terhadap pertanyaan "Produk pada Warunk Upnormal cabang Dipatiukur sangat beragam”. Hasil yang didapat yaitu 17 responden menjawab "Sangat Setuju”, 64 responden menjawab "Setuju”, 18 responden menjawab “Cukup Setuju”, 1 responden menjawab “Tidak Setuju”, dan 0 responden menjawab “Sangat Tidak Setuju”. Hal tersebut membuktikan bahwa sebagian besar konsumen setuju bahwa ragam pilihan produk yang disediakan Warunk Upnormal cabang Dipatiukur telah sudah sangat beragam, dapat 
dilihat dari sebagian besar konsumen menjawab setuju bahwa produk pada Warunk Upnormal cabang Dipatiukur sangat beragam. Hal ini seperti ditunjukan dalam Tabel 4.

Tabel 4. Item no. 2

\begin{tabular}{clccccc}
\hline No & Pertanyaan & Jawaban & Bobot & F & \% & Skor \\
\hline 2. & Produk pada & SS & 5 & 17 & $17 \%$ & 85 \\
& Warunk Upnormal & S & 4 & 64 & $64 \%$ & 256 \\
cabang Dipatiukur & CS & 3 & 18 & $18 \%$ & 54 \\
sangat beragam. & TS & 2 & 1 & $1 \%$ & 2 \\
& STS & 1 & 0 & $0 \%$ & 0 \\
\multicolumn{2}{c}{ TOTAL } & & & 100 & $100 \%$ & 397 \\
\multicolumn{2}{c}{ RATA-RATA } & & & & 3.97 \\
\hline
\end{tabular}

Sumber : Data Diolah (2018)

\section{Tanggapan Responden Mengenai Kekuatan Asosiasi Merek}

Berdasarkan variabel citra merek dengan dimensi kekuatan asosiasi merek, tanggapan responden terhadap pertanyaan "Saya mengetahui informasi terkait Warunk Upnormal cabang Dipatiukur melalui sosial media” yaitu 80 responden memilih "Instagram”, 12 responden menjawab “Facebook”, 8 responden menjawab “Twitter”, dan 0 responden menjawab "lainnya. Hal tersebut menunjukkan bahwa sebagian besar responden mengetahui informasi terkait Warunk Upnormal cabang Dipatiukur melalui sosial media "Instagram” dilihat dari presentase pemilihan responden terhadap "Instagram” yang sangat dominan yaitu $80 \%$.

Tabel 5. Item no. 3

\begin{tabular}{ccccccc}
\hline No & Pertanyaan & Jawaban & Bobot & F & \% & Skor \\
\hline 3. & Warunk Upnormal & SS & 5 & 8 & $8 \%$ & 40 \\
& cabang Dipatiukur & S & 4 & 75 & $75 \%$ & 300 \\
selalu melakukan & CS & 3 & 16 & $16 \%$ & 48 \\
inovasi yang baru & TS & 2 & 1 & $1 \%$ & 2 \\
pada menu. & STS & 1 & 0 & $0 \%$ & 0 \\
\multicolumn{2}{c}{ TOTAL } & & & 100 & $100 \%$ & 390 \\
RATA-RATA & & & & 3.90 \\
\hline
\end{tabular}

Sumber : Data diolah (2018) 
Berdasarkan variabel citra merek dengan dimensi kekuatan asosiasi merek, didapat tanggapan responden terhadap pertanyaan "Warunk Upnormal cabang Dipatiukur selalu melakukan inovasi yang baru pada menu” yaitu 8 responden menjawab "Sangat Setuju”, 75 responden menjawab “Setuju”, 16 responden menjawab “Cukup Setuju”, 1 responden menjawab “Tidak Setuju”, dan 0 responden menjawab "Sangat Tidak Setuju”. Hal tersebut membuktikan bahwa sebagian besar konsumen setuju bahwa Warunk Upnormal cabang Dipatiukur selalu melakukan inovasi terhadap menu-menunya, dapat dilihat dari sebagian besar konsumen menjawab setuju bahwa Warunk Upnormal cabang Dipatiukur selalu melakukan inovasi terhadap menunya. Hal ini seperti ditunjukan dalam tabel 5.

\section{Tanggapan Responden Mengenai Keunikan Asosiasi Merek}

Berdasarkan variabel citra merek dengan dimensi keunikan asosiasi merek, didapat tanggapan responden terhadap pertanyaan "Menu yang disediakan Warunk Upnormal cabang Dipatiukur memiliki keunikan dan berbeda dari produk lainnya” yaitu 21 responden menjawab "Sangat Setuju”, 52 responden menjawab "Setuju”, 26 responden menjawab “Cukup Setuju”, 1 responden menjawab “Tidak Setuju”, dan 0 responden menjawab "Sangat Tidak Setuju”. Hal tersebut membuktikan bahwa sebagian besar konsumen setuju bahwa menu yang disediakan oleh Warunk Upnormal cabang Dipatiukur mempunyai keunikan dan berbeda dari produk lainnya, dapat dilihat dari sebagian besar konsumen menjawab setuju bahwa produk Warunk Upnormal mempunyai keunikan dan berbeda dari produk lainnya. Hal ini seperti ditunjukan dalam tabel 6.

Tabel 6. Item no. 4

\begin{tabular}{clccccc}
\hline No & \multicolumn{1}{c}{ Pertanyaan } & Jawaban & Bobot & F & \% & Skor \\
\hline 4. & Menu yang & SS & 5 & 21 & $21 \%$ & 105 \\
& $\begin{array}{l}\text { disediakan Warunk } \\
\text { Upnormal cabang }\end{array}$ & S & 4 & 52 & $52 \%$ & 208 \\
& Dipatiukur memiliki & CS & 3 & 26 & $26 \%$ & 78 \\
keunikan dan berbeda & TS & 2 & 1 & $1 \%$ & 2 \\
dari produk lainnya. & STS & 1 & 0 & $0 \%$ & 0 \\
\multicolumn{2}{c}{ TOTAL } & & & 100 & $100 \%$ & 393 \\
RATA-RATA & & & & 3.93 \\
\hline
\end{tabular}

Sumber : Data diolah (2018) 
Berdasarkan variabel citra merek dengan dimensi keunikan asosiasi merek, didapat tanggapan responden terhadap pertanyaan "Warunk Upnormal cabang Dipatiukur memiliki fasilitas yang lengkap” yaitu 21 responden menjawab "Sangat Setuju”, 53 responden menjawab "Setuju”, 26 responden menjawab “Cukup Setuju”, 0 responden menjawab “Tidak Setuju”, dan 0 responden menjawab "Sangat Tidak Setuju”. Hal tersebut membuktikan bahwa sebagian besar konsumen setuju bahwa fasilitas yang disediakan Warunk Upnormal cabang Dipatiukur telah lengkap, dapat dilihat dari sebagian besar konsumen menjawab setuju bahwa fasilitas yang disediakan Warunk Upnormal cabang Dipatiukur telah memadai dan lengkap. Hal ini seperti ditunjukan dalam tabel 7.

Tabel 7. Item No. 5

\begin{tabular}{ccccccc}
\hline No & \multicolumn{1}{c}{ Pertanyaan } & Jawaban & Bobot & F & \% & Skor \\
\hline 5. & Warunk Upnormal & SS & 5 & 21 & $21 \%$ & 105 \\
cabang Dipatiukur & S & 4 & 53 & $53 \%$ & 212 \\
memiliki fasilitas & CS & 3 & 26 & $26 \%$ & 78 \\
yang lengkap. & TS & 2 & 0 & $0 \%$ & 0 \\
& STS & 1 & 0 & $0 \%$ & 0 \\
\multicolumn{2}{c}{ TOTAL } & & & 100 & $100 \%$ & 395 \\
RATA-RATA & & & & 3.95
\end{tabular}

Sumber : Data diolah (2018)

\section{Tanggapan Responden Mengenai Karakteristik Keputusan Pembelian}

\section{Tanggapan Responden Mengenai Faktor Budaya}

Berdasarkan variabel keputusan pembelian dengan dimensi Faktor Budaya, didapat tanggapan responden terhadap pertanyaan "Warunk Upnormal cabang Dipatiukur memiliki pelayanan yang baik" yaitu 24 responden menjawab "Sangat Setuju”, 45 responden menjawab "Setuju”, 22 responden menjawab “Cukup Setuju”, 0 responden menjawab "Tidak Setuju”, dan 0 responden menjawab "Sangat Tidak Setuju”. Hal tersebut membuktikan bahwa sebagian besar konsumen setuju bahwa pelayanan yang diberikan oleh Warunk Upnormal cabang Dipatiukur telah baik, dapat dilihat dari sebagian besar konsumen menjawab setuju bahwa pelayanan yang diberikan oleh Warunk Upnormal cabang Dipatiukur telah baik.Hal ini seperti ditunjukan dalam Tabel 8. 
Tabel 8. Item no. 6

\begin{tabular}{ccccccc}
\hline No & \multicolumn{1}{c}{ Pertanyaan } & Jawaban & Bobot & F & \% & Skor \\
\hline 6. & Warunk Upnormal & SS & 5 & 24 & $24 \%$ & 120 \\
cabang Dipatiukur & S & 4 & 45 & $45 \%$ & 180 \\
memiliki pelayanan & CS & 3 & 22 & $22 \%$ & 66 \\
yang baik. & TS & 2 & 0 & $0 \%$ & 0 \\
& STS & 1 & 0 & $0 \%$ & 0 \\
\multicolumn{2}{c}{ TOTAL } & & & 100 & $100 \%$ & 366 \\
RATA-RATA & & & & 3.66 \\
\hline
\end{tabular}

Sumber : Data diolah (2018)

Berdasarkan variabel keputusan pembelian dengan dimensi Faktor Budaya, didapat tanggapan responden terhadap pertanyaan "Saya lebih memilih mengunjungi Warunk Upnormal cabang Dipatiukur dibandingkan dengan cafe/restoran lainnya.” yaitu 13 responden menjawab "Sangat Setuju”, 58 responden menjawab "Setuju”, 27 responden menjawab "Cukup Setuju”, 2 responden menjawab “Tidak Setuju”, dan 0 responden menjawab "Sangat Tidak Setuju". Hal tersebut membuktikan bahwa sebagian besar konsumen setuju lebih memilih mengunjungi Warunk Upnormal cabang Dipatiukur dibandingkan cafe/restoran lainnya, dapat dilihat dari sebagian besar konsumen menjawab setuju memilih mengunjungi Warunk Upnormal cabang Dipatiukur dibandingkan cafe/restoran lainnya. Hal ini seperti ditunjukan dalam tabel 9.

Tabel 9. Item No. 7

\begin{tabular}{|c|c|c|c|c|c|c|}
\hline No & Pertanyaan & Jawaban & Bobot & $\mathbf{F}$ & $\%$ & Skor \\
\hline \multirow[t]{7}{*}{7.} & Saya lebih memilih & SS & 5 & 13 & $13 \%$ & 65 \\
\hline & mengunjungi & S & 4 & 58 & $58 \%$ & 253 \\
\hline & Warunk Upnormal & CS & 3 & 27 & $27 \%$ & 81 \\
\hline & $\begin{array}{l}\text { cabang Dipatiukur } \\
\text { dibandingkan dengan }\end{array}$ & TS & 2 & 2 & $2 \%$ & 4 \\
\hline & cafe/restoran lainnya. & STS & 1 & 0 & $0 \%$ & 0 \\
\hline & \multicolumn{2}{|l|}{ TOTAL } & & 100 & $100 \%$ & 403 \\
\hline & \multicolumn{2}{|c|}{ RATA-RATA } & & & & 4.03 \\
\hline
\end{tabular}

Sumber : Data diolah (2018) 


\section{Tanggapan Responden Mengenai Faktor Sosial}

Berdasarkan variabel keputusan pembelian dengan dimensi Faktor Sosial, didapat tanggapan responden terhadap pertanyaan "Saya mengunjungi Warunk Upnormal cabang Dipatiukur karena terpengaruh oleh ajakan/saran dari teman-teman saya” yaitu 20 responden menjawab "Sangat Setuju”, 58 responden menjawab "Setuju”, 17 responden menjawab “Cukup Setuju”, 5 responden menjawab “Tidak Setuju”, dan 0 responden menjawab "Sangat Tidak Setuju”. Hal tersebut membuktikan bahwa sebagian besar konsumen setuju terpengaruh oleh ajakan/saran dari teman saat mengunjungi Warunk Upnormal cabang Dipatiukur, dapat dilihat dari sebagian besar konsumen menjawab setuju konsumen terpengaruh oleh ajakan/saran dari teman saat mengunjungi Warunk Upnormal cabang Dipatiukur. Hal ini seperti ditunjukan dalam tabel 10 berikut ini:

Tabel 10.Item no. 8

\begin{tabular}{ccccccc}
\hline No & Pertanyaan & Jawaban & Bobot & F & \% & Skor \\
\hline 8. & Saya mengunjungi & SS & 5 & 20 & $20 \%$ & 100 \\
$\begin{array}{l}\text { Warunk Upnormal } \\
\text { cabang Dipatiukur }\end{array}$ & S & 4 & 58 & $58 \%$ & 232 \\
karena terpengaruh & CS & 3 & 17 & $17 \%$ & 51 \\
oleh ajakan/saran & TS & 2 & 5 & $5 \%$ & 10 \\
dari teman-teman & STS & 1 & 0 & $0 \%$ & 0 \\
saya. & TOTAL & & 100 & $100 \%$ & 393 \\
RATA-RATA & & & & 3.93 \\
\hline
\end{tabular}

Sumber : Data diolah (2018)

Berdasarkan variabel keputusan pembelian dengan dimensi Faktor Sosial, didapat tanggapan responden terhadap pertanyaan "Saya mengunjungi Warunk Upnormal cabang Dipatiukur karena pengaruh/dorongan yang diberikan oleh keluarga saya”yaitu 15 responden menjawab "Sangat Setuju”, 46 responden menjawab "Setuju”, 31 responden menjawab “Cukup Setuju”, 8 responden menjawab “Tidak Setuju”, dan 0 responden menjawab "Sangat Tidak Setuju”. Hal tersebut membuktikan bahwa sebagian besar konsumen setuju bahwa saat mengunjungi Warunk Upnormal cabang Dipatiukur terdapat dorongan dari keluarga, dapat 
dilihat dari sebagian besar konsumen menjawab setuju telah mendapatkan dororang/pengaruh dari keluarga saat mengunjungi Warunk Upnormal cabanag Dipatiukur.Hal ini seperti ditunjukan dalam Tabel 11.

Tabel 11. Item no.9

\begin{tabular}{llccccc}
\hline No & Pertanyaan & Jawaban & Bobot & F & \% & Skor \\
\hline 9. & Saya mengunjungi & SS & 5 & 15 & $15 \%$ & 75 \\
& Warunk Upnormal & S & 4 & 46 & $46 \%$ & 184 \\
cabang Dipatiukur & CS & 3 & 31 & $31 \%$ & 93 \\
karena & TS & 2 & 8 & $8 \%$ & 16 \\
pengaruh/dorongan & & & & & \\
yang diberikan oleh & & & & & \\
keluarga saya. & STS & 1 & 0 & $0 \%$ & 0 \\
$\quad$ TOTAL & & & 100 & $100 \%$ & 368 \\
RATA-RATA & & & & 3.68 \\
\hline
\end{tabular}

Sumber : Data diolah (2018)

\section{Tanggapan Responden Mengenai Faktor Pribadi}

Berdasarkan variabel keputusan pembelian dengan dimensi Faktor Pribadi, didapat tanggapan responden terhadap pertanyaan "Saya mengunjungi Warunk Upnormal cabang Dipatiukur karena Warunk Upnormal cabang Dipatiukur dapat merefleksikan status sosial saya” yaitu 20 responden menjawab "Sangat Setuju”, 54 responden menjawab "Setuju”, 3 responden menjawab “Cukup Setuju”, 2 responden menjawab “Tidak Setuju”, dan 1 responden menjawab “Sangat Tidak Setuju”. Hal tersebut membuktikan bahwa sebagian besar konsumen setuju bahwa saat mengunjungi Warunk Upnormal cabang Dipatiukur dapat merefleksikan status sosial konsumen, dapat dilihat dari sebagian besar konsumen menjawab setuju bahwa saat mengunjungi Warunk Upnormal cabang Dipatiukur dapat merefleksikan status sosial konsumen. 
Tabel 12. Item no. 10

\begin{tabular}{clccccc}
\hline No & \multicolumn{1}{c}{ Pertanyaan } & Jawaban & Bobot & F & \% & Skor \\
\hline 10. & Saya mengunjungi & SS & 5 & 20 & $20 \%$ & 100 \\
& Warunk Upnormal & S & 4 & 54 & $54 \%$ & 216 \\
cabang Dipatiukur & CS & 3 & 23 & $23 \%$ & 69 \\
karena Warunk & TS & 2 & 0 & $0 \%$ & 0 \\
Upnormal cabang & & & & & \\
Dipatiukur dapat & & & & & \\
merefleksikan status & & & & & \\
sosial saya. & STS & 1 & 1 & $1 \%$ & 1 \\
$\quad$ TOTAL & & & 100 & $100 \%$ & 386 \\
RATA-RATA & & & & 3.86 \\
\hline
\end{tabular}

Sumber : Data diolah (2018)

Berdasarkan variabel keputusan pembelian dengan dimensi Faktor Pribadi, didapat tanggapan responden terhadap pertanyaan "Saya mengunjungi Warunk Upnormal cabang Dipatiukur karena harga yang disediakan sesuai dengan pendapatan/uang saku yang saya miliki”yaitu 25 responden menjawab “Sangat Setuju”, 52 responden menjawab "Setuju”, 25 responden menjawab "Cukup Setuju”, 0 responden menjawab “Tidak Setuju”, dan 0 responden menjawab "Sangat Tidak Setuju”. Hal tersebut membuktikan bahwa sebagian besar konsumen setuju bahwa harga yang disediakan Warunk Upnormal cabang Dipatiukur sesuai dengan pendapatan/uang saku yang dimiliki konsumen, dapat dilihat dari sebagian besar konsumen menjawab setuju bahwa saat mengunjungi Warunk Upnormal cabang Dipatiukur dapat merefleksikan status sosial konsumen. Hal ini seperti ditunjukan dalam Tabel 11. 
Tabel 13. Item no. 11

\begin{tabular}{ccccccc}
\hline No & Pertanyaan & Jawaban & Bobot & F & \% & Skor \\
\hline 11. & Saya mengunjungi & SS & 5 & 25 & $25 \%$ & 125 \\
$\begin{array}{l}\text { Warunk Upnormal } \\
\text { cabang Dipatiukur }\end{array}$ & S & 4 & 52 & $52 \%$ & 208 \\
karena harga yang & & & & & \\
disediakan sesuai & CS & 3 & 25 & $25 \%$ & 75 \\
dengan & & & & & \\
$\begin{array}{l}\text { pendapatan/uang saku } \\
\text { yang saya miliki. }\end{array}$ & TS & 2 & 0 & $0 \%$ & 0 \\
$\quad$ TOTAL & & 1 & 0 & $0 \%$ & 0 \\
RATA-RATA & & & 100 & $100 \%$ & 408 \\
&
\end{tabular}

Sumber : Data diolah (2018)

\section{Tanggapan Responden Terhadap Faktor Psikologis}

Berdasarkan variabel keputusan pembelian dengan dimensi Faktor Psikologis, didapat tanggapan responden terhadap pertanyaan "Saya mengunjungi Warunk Upnormal cabang Dipatiukur karena tempatnya yang menyenangkan untuk berkumpul bersama kelompok saya” yaitu 17 responden menjawab "Sangat Setuju”, 68 responden menjawab "Setuju”, 14 responden menjawab "Cukup Setuju”, 0 responden menjawab “Tidak Setuju”, dan 1 responden menjawab "Sangat Tidak Setuju”. Hal tersebut membuktikan bahwa sebagian besar konsumen setuju bahwa Warunk Upnormal cabang Dipatiukur adalah tempat yang menyenangkan untuk berkumpul bersama kelompok acuan konsumen, dapat dilihat dari sebagian besar konsumen menjawab setuju bahwa Warunk Upnormal cabang Dipatiukur adalah tempat yang menyenangkan untuk berkumpul bersama kelompok acuan konsumen. Hal ini seperti ditunjukan dalam Tabel 14. 
Tabel 14. Item no. 12

\begin{tabular}{ccccccc}
\hline No & \multicolumn{1}{c}{ Pertanyaan } & Jawaban & Bobot & F & \% & Skor \\
\hline 12. & Saya mengunjungi & SS & 5 & 17 & $17 \%$ & 85 \\
& $\begin{array}{l}\text { Warunk Upnormal } \\
\text { cabang Dipatiukur }\end{array}$ & S & 4 & 68 & $68 \%$ & 272 \\
karena tempatnya yang & CS & 3 & 14 & $14 \%$ & 42 \\
$\begin{array}{l}\text { menyenangkan untuk } \\
\text { berkumpul bersama }\end{array}$ & TS & 2 & 0 & $0 \%$ & 0 \\
kelompok saya. & STS & 1 & 1 & $1 \%$ & 1 \\
TOTAL & & & 100 & $100 \%$ & 400 \\
RATA-RATA & & & & & 4.00
\end{tabular}

Sumber: Data diolah (2018)

Berdasarkan variabel keputusan pembelian dengan dimensi Faktor Psikologis, didapat tanggapan responden terhadap pertanyaan "Saya mengunjungi Warunk Upnormal cabang Dipatiukur berdasarkan pengalaman baik yang telah saya dan orang disekitar saya rasakan”yaitu 18 responden menjawab "Sangat Setuju”, 56 responden menjawab “Setuju”, 25 responden menjawab “Cukup Setuju”, 1 responden menjawab “Tidak Setuju”, dan 0 responden menjawab “Sangat Tidak Setuju”. Hal tersebut membuktikan bahwa sebagian besar konsumen setuju bahwa saat mengunjungi Warunk Upnormal cabang Dipatiukur berdasarkan pengalaman baik yang telah mereka dan orang sekitar mereka rasakan, dapat dilihat dari sebagian besar konsumen menjawab setuju saat mengunjungi Warunk Upnormal cabang Dipatiukur berdasarkan pengalaman baik yang telah mereka dan orang sekitar mereka rasakan. Hal ini seperti ditunjukan dalam Tabel 15. 
Tabel 15. Item no 13

\begin{tabular}{|c|c|c|c|c|c|c|}
\hline No & Pertanyaan & Jawaban & Bobot & $\mathbf{F}$ & $\%$ & Skor \\
\hline \multirow[t]{10}{*}{13.} & Saya mengunjungi & & & & & \\
\hline & Warunk Upnormal & SS & 5 & 18 & $18 \%$ & 90 \\
\hline & cabang Dipatiukur & S & 4 & 56 & $56 \%$ & 224 \\
\hline & berdasarkan & & & & & \\
\hline & pengalaman baik & CS & 3 & 25 & $25 \%$ & 75 \\
\hline & yang telah saya dan & & & & & \\
\hline & orang disekitar saya & TS & 2 & $1 \%$ & $1 \%$ & 1 \\
\hline & rasakan. & STS & 1 & 0 & $0 \%$ & 0 \\
\hline & TOTA & & & 100 & $100 \%$ & 390 \\
\hline & RATA-R & & & & & 3.90 \\
\hline
\end{tabular}

Sumber : Datadiolah (2018)

\section{Skor Variabel}

Berikut ini adalah hasil pengolahan skor dari setiap variabel beserta rata-rata skor dari seluruh variabel citra merek (Tabel 16) dan seluruh variabel keputusan pembelian(Tabel 17).

Tabel 16. Variabel Citra Merek

\begin{tabular}{cccc}
\hline No & \multicolumn{1}{c}{ Sub Variabel } & Skor & Keterangan \\
\hline 1. & Keunggulan Asosiasi Merek & 4.02 & Baik \\
2. & Kekuatan Asosisasi Merek & 3.9 & Baik \\
3. Keunikan Asosiasi Merek & 3.94 & Baik \\
RATA-RATA SKOR & 3.95 & Baik \\
\hline
\end{tabular}

Sumber : Data diolah (2018)

Berdasarkan variabel citra merek dengan sub variabel keunggulan asosiasi merek, kekuatan asosiasi merek, dan keunikan asosiasi merek, didapat hasil rata-rata perhitungan skor pada setiap sub variabel.Untuk keunggulan asosiasi merek memiliki skor 4.02 yakni dapat diartikan baik, kekuatan asosiasi merek memiliki skor 3.9 yakni dapat diatikan baik, keunikan asosiasi merek memiliki skor 3.94 yakni dapat diartikan baik. Dari seluruh skor yang didapatkan melalui sub variabel, didapatkan hasil rata-rata skor dari variabel citra merek 3.95 yakni dapat diartikan baik. Hal ini membuktikan bahwa pendapat atau pandangan 
konsumen mengenai citra merek Warunk Upnormal cabang Dipatiukur yang telah dituangkan kedalam beberapa indikator citra merek pada kuisioner adalah baik.

Tabel 17.Variabel Keputusan Pembelian

\begin{tabular}{llcc}
\hline No & \multicolumn{1}{c}{ Sub Variabel } & Skor & Keterangan \\
\hline 1. & Faktor Budaya & 3.84 & Baik \\
2. & Faktor Sosial & 3.80 & Baik \\
3. & Faktor Pribadi & 3.97 & Baik \\
4. $\quad$ Faktor Psikologis & 3.95 & Baik \\
TOTAL SKOR RATA- & 3.89 & Baik \\
RATA & & \\
\hline
\end{tabular}

Sumber : Data Diolah (2018)

Berdasarkan variabel keputusan pembelian dengan sub variabel faktor budaya, faktor sosial, faktor pribadi, dan faktor psikologis, didapat hasil rata-rata perhitungan skor pada setiap sub variabel.Untuk faktor budaya sebesar 3.84 yang artinya baik, faktor sosial sebesar 3.80 yang artinya baik, faktor pribadi sebesar 3.97 yang artinya baik, dan faktor psikologis sebesar 3,95 yang artinya baik. Dari seluruh skor sub variabel dari keputusan pembelian, didapat hasil perhitungan rata-rata skor dari variabel keputusan pembelian yakni sbenesar 3.89 yang artinya baik.

\section{KESIMPULAN}

Variabel citra merek pada Warunk Upnormal cabang Dipatiukur memiliki hasil skor sebesar 3.95 yaitu dapat diartikan baik. Hal ini membuktikan bahwa pendapat atau pandangan konsumen mengenai citra merek Warunk Upnormal cabang Dipatiukur yang telah dituangkan kedalam beberapa indikator citra merek pada kuisioner adalah baik. Namun, untuk mempertahankan loyalitas konsumen pada Warunk Upnormal cabang Dipatiukur, perlu dilakukan beberapa perbaikan dan peningkatan kualitas. Terkait dengan skor sub variabel dari keputusan pembelian, didapat hasil perhitungan rata-rata skor dari variabel keputusan pembelian yakni sbenesar 3.89 yang artinya baik. Hal ini membuktikan bahwa faktor-faktor keputusan pembelian yang telah diuraikan kedalam beberapa indikator pernyataan yang tertuang kedalam kuisioner mempengaruhi konsumen dalam pengambilan keputusan pembelian konsumen pada Warunk Upnormal Cabang Dipatiukur. 
Berdasarkan kesimpulan serta hasil data yang telah diolah, kami menyampaikan saran bahwa Warunk Upnormal cabang Dipatiukur perlu meningkatkan kegiatan promosinya melalui sosial media Instagram, Facebook dan Twitteragar konsumen memiliki daya ingat yang kuat terhadap citra pada Warunk Upnormal cabang Dipatiukur. Hal ini terlihat dari hasil penelitian bahwa mayoritas responden mengenali Warung Upnormal dari sosial media, khususnya Instagram. Sehingga,hal ini nantinya akan berdampak positif terhadap keputusan konsumen untuk memilih Warunk Upnormal cabang Dipatiukur sebagai café pilihannya. Warunk Upnormal cabang Dipatiukur juga perlu meningkatkan kualitas produk khususnya pada variasi menu. Dengan ada peningkatan variasi menu yang lebih inovatif, maka hal ini berdampak positif pada keputusan pembelian konsumen pada Warunk Upnormal cabang Dipatiukur.

\section{DAFTAR PUSTAKA}

Asmarazisa, D. (2014). Analisis Pengaruh Brand Image Terhadap Pengambilan Keputusan Konsumen pada PT. Surya Madistrindo Batam. Jurnal Equilibria, 1(1), 1-11.

Evita Nurul. (2017). Pengaruh Citra Merek Terhadap Keputusan Pembelian (Studi Kasus Pada Bakso Boedjangan Cabang Burangrang Bandung Tahun 2017). E-Proceeding of Applied Science, Vol.3(2), 430-438.

Ferrinadewi, Erna. (2008). Merek \& Psikologi Konsumen: Implikasi pada Strategi Pemasaran. Edisi Pertama, Cetakan Pertama. Yogyakarta: Graha Ilmu

Hakim, L. (2016). Analisis Pengaruh Brand Image terhadap Keputusan Konsumen pada BPR Sejahtera Batam. Jurnal Dimensi, 1(1), 1-15.

Jumlah Restoran/Rumah Makan di Kota Bandung tahun 2016. (2016). Retrieved March 20, 2018, from https://bandungkota.bps.go.id/statictable/2017/08/29/121/-jumlah-restoranrumah-makan-di-kota-bandung-2016.html

Keller, K.L. (1998). Strategic Brand Management: Building, Measuring, and Managing Brand Equity, New Jersey: Prentice Hall

Kotler, P. (2002). Manajemen Pemasaran, Jilid 1, Edisi Milenium. Jakarta: Prehallindo.

Lestari, I. I. (2011). Analisis Pengaruh Brand Image Terhadap Keputusan Nasabah dalam Memilih Tabungan pada PT. Bank Central Asia Cabang Probolinggo. Universitas Jember.

Listyawati, I. H. (2014). Analisis Pengaruh Citra Merek Terhadap Keputusan Pembelian Kartu Simpati Di Yogyakarta. Jurnal JBMA, II(1), 37-52. 
Musay, F. P. (2013). Pengaruh Brand Image terhadap Keputusan Pembelian. Universitas Brawijaya. Retrieved from https:/media.neliti.com/media/publications/74236-IDpengaruh-brand-image-terhadap-keputusan.pdf

Romadhoni, M. (2015). Pengaruh Citra Merek Terhadap Pengambilan Keputusan Pembelian Sepatu Nike pada Mahasiaswa FIK UNY. Universitas Negeri Yogyakarta.

Setiadi, N.J. (2003). Perilaku Konsumen: Konsep dan Implikasi untuk Strategi dan Penelitian Pemasaran. Jakarta: Prenada Media

Sulistyawati, P. (2011). Analisis Pengaruh Citra Merek dan Kualitas Produk TerhadapKeputusan Pembelian Laptop Merek Acer di Kota Semarang. Universitas Diponegoro Semarang.

Syoalehat, Q. N., Azizah, S., \& Kusumastuti, A. E. (2016). Pengaruh Citra Merek (Brand Image) Terhadap Loyalitas Konsumen Bakso Bakar Pak Man Kota Malang. Jurnal Ilmu-Ilmu Peternakan, 26(3), 20-26.

Widagdyo, K. G. (2017). Pemasaran, Daya Tarik Ekowisata, dan Minat Berkunjung Wisatawan. Esensi: Jurnal Bisnis Dan Manajemen, 7(2), 261-276. https://doi.org/10.15408/ess.v7i2.5411 